\title{
Criminology and Socio- Cultural Aspects of the Anti-Dowry Law in India: A Feminist Critique
}

\author{
Chitwan Varma \\ Post Doctoral Fellow [ICSSR], BB Ambedkar Central University, Lucknow (U.P), India and Associate Professor \\ JNPG College, Lucknow, India.
}

\begin{abstract}
In India, the custom of dowry [payment of cash /gifts from the bride family to the bridegroom's family at marriage] not only encouraged parents to be sex selective and abort female embryos [causing skewed sex ratio] and greedy husbands and in-laws to torture and burn brides if their demands were not satiated, it also lowered women status/equality drastically. As a political positive corrective and feminist intervention the government not only banned dowry, it also introduced section 498-A in the Indian Penal Code - a non -bail able, non-compoundable and cognizable offence, against husband or relative, on cruelty to a married woman. But the law is dysfunctional due to lack of awareness, illiteracy, socio-cultural factors \& joint family system. Sometimes all the adults of the family are put in jail along with infants, just on complaint, without investigations with school going children left alone to fend for themselves. On the basis of data of four districts of Bundelkhand in India where more than $40 \%$ of women jail inmates are under trials for s498A, the paper questions the criminology and impact of reforms/laws alone to curtail gender-based violence, when the basic values within the family, community and state remain patriarchal and against women.
\end{abstract}

Feminism has its roots as a political intervention into patriarchy. In India, the legal prohibition [1] of dowry (payment of cash or gifts from the brides family to the bridegroom's family upon marriage) has its roots as a political intervention into patriarchy. As traditional institutional knowledge dowry not only encouraged parents to be sex selective and abort daughters (causing skewed sex ratio) but also encouraged greedy husbands and in-laws to burn brides if their demands were not satiated.

\section{Bride burning in India}

In India, initially dowry was a means of providing support to the newlywed girl by her parents especially as child marriage was the norm. With lack of education and empowering tools and total economic dependence women began to be considered a burden. Their own worth became less and so dowry seemed compensation rather than a gift. In a patriarchal system these girls have to concede to every wish of not only the man of the house but also the elderly women who conspired to kill her if demand for dowry were not met. Killing the young bride meant another bride and dowry for greedy in-laws.
We may speculate as to why a mother-in-law, who is another woman, assist in killing her own daughter-inlaw. V.Geetha explains, " clearly this does not explain or help the truly confused to make sense of the vicious and deeply felt jealousy and anxiety contained in the mother-in-law's attitude towards her young bride. Afraid of losing her place in her son's life, helpless before the curious and happy sexuality of the young woman, determined to put to use a power that has eluded her when she was young, the mother-in-law is not merely a victim of a system, but also one of its constituent elements." [2]

Domestic violence, though very common in India, was considered a family matter till 1970's and the criminal judicial system had sought to keep answerability for these crimes in the home rather than using the lawful system as a deterrent.

Bride burning incidents first hit the headlines in India through images of gruesomely charred bodies of young married women in the capital city of Delhi in the late seventies. [3] The parents of the women suffering these blood-curdling brutalities revealed their plight through mass media. These were firstly dismissed as freak accidents by the investigators. They were called the 'stove deaths' as allegedly in-laws/ husband would 
throw stove kerosene on the women and they would die with $90 \%$ or more burns.

\section{The Anti-Dowry Law}

Due to continuous campaigning by women groups and media glare the government introduced a stringent section 498-A in the IPC in 1983 in addition to existing dowry prohibition act of 1961. As per new law, whoever, be it the husband or the relative of the husband of a woman, subjects her to cruelty shall be punished with imprisonment for a term, which may extend to three years and shall also be liable to fine. This section is non- bail able, non compoundable (complaint can't be withdrawn) and cognizable (police is free to register and investigate complaint).

The focus of public protests, were state culpability, policy apathy and corruption. In this emotionally charged atmosphere, there was no time to address other related issues. Hence the underlying but critical concerns such as the subordinate status of women within their natal and martial home, the issues of property ownership within their natal homes, the control of women's sexuality, the stigma attached to divorce and the lack of support for the girl in her natal home after she has been "married off"-these could not get articulated within the emotionally charged atmosphere of the anti-dowry protests. [4]

The section was viewed mainly as a provision for making immediate arrest without warrant. The social stigma of arrest, it was hoped, would act as a deterrent.

In practice, most of the time, arrests happen before any investigation. Thus there have been countless instances where, without full investigation, the police arrested elderly parents, unmarried sisters, brothers-inlaw, pregnant sisters-in-law and even their small children. In rural India, where due to lack of awareness, illiteracy, the joint family system still being prevalent, this law is playing havoc in many families. Sometimes all the adults of the family are in jail along with their infants and school going children are left all alone at home to fend for them selves.

\section{Reported Cases of Dowry Deaths in India}

At the national level as shown in a report by the National Crime Record Bureau (NCRB)there has been a considerable rise in the reported cases of bride burning in India.

Table 1.

\begin{tabular}{|l|l|l|l|l|l|l|l|l|l|}
\hline Year & 1990 & 1994 & 1995 & 1996 & 1997 & 1998 & 2007 & 2008 & 2009 \\
\hline $\begin{array}{l}\text { Dowry } \\
\text { Deaths }\end{array}$ & 4836 & 4935 & 5092 & 5513 & 6006 & 6917 & 8093 & 8172 & 8383 \\
\hline
\end{tabular}

Source: Crime in India, national crime record bureau (NCRB), ministry of home affairs, government of India

But rather disturbingly, the visibility in the numbers of reported cases did not add up to conviction rates. For instance as per the national crime records bureau of India (NCRB) reports for 2008, there were 1948 convictions as against 3876 acquittals. It was obvious that the law did not act as a deterrent as it had been perceived... . Even if the giving and taking of dowry had been effectively constrained, the girls would not have benefitted and suicides of married women would have continued unabated as the murders and suicides are a reflection of the vulnerable position of the girl in her natal home and the stigma attached to divorce."[5]

\section{Grass root Reality}

This is the primary data of prison inmates for the year 2012 of four districts of the backward and povertystricken Bundelkhand area of Uttar Pradesh in India. People in this area are mainly an agrarian society deeply rooted in religious beliefs and ritualistic practices.

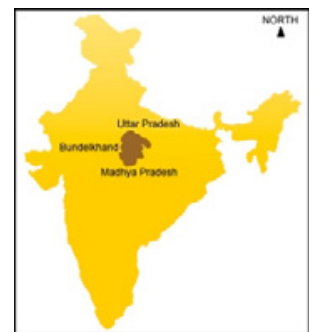

Figure 1. Bundelkhand in India

Table 2. Source-Government of UP jail data.

\begin{tabular}{|c|c|c|c|c|c|c|c|c|}
\hline $\begin{array}{l}\text { S. } \\
\text { No. }\end{array}$ & $\begin{array}{c}\text { Name of } \\
\text { Jail }\end{array}$ & \multicolumn{2}{|c|}{$\begin{array}{l}\text { 1 otal no. of } \\
\text { prisoners }\end{array}$} & \multicolumn{2}{|c|}{$\begin{array}{c}\text { No. of men } \\
\text { detained under } \\
\text { 498A }\end{array}$} & \multicolumn{2}{|c|}{$\begin{array}{l}\text { No. of women } \\
\text { detained under } \\
\text { 498A }\end{array}$} & \begin{tabular}{|c} 
Children \\
in jail \\
with \\
mothers \\
\end{tabular} \\
\hline \multirow[t]{4}{*}{1} & \multirow{2}{*}{\begin{tabular}{|c} 
District \\
Jail Banda \\
$\&$ \\
Chtrakoot
\end{tabular}} & Men & Women & \multirow{2}{*}{\multicolumn{2}{|c|}{216}} & \multirow{2}{*}{\multicolumn{2}{|c|}{31}} & \multirow{2}{*}{08} \\
\hline & & 863 & 43 & & & & & \\
\hline & & & & $\begin{array}{c}\text { Under } \\
\text { trial }\end{array}$ & Convicts & $\begin{array}{c}\text { Under } \\
\text { trial }\end{array}$ & Convicts & \\
\hline & & & & 197 & 19 & 22 & 09 & \\
\hline 2 & District & Men & Women & & 01 & 0 & & 02 \\
\hline & Hamirpur & 455 & 13 & & & & & \\
\hline & & & & $\begin{array}{c}\text { Under } \\
\text { trial }\end{array}$ & Convicts & $\begin{array}{c}\text { Under } \\
\text { trial }\end{array}$ & Convicts & \\
\hline & & & & 01 & 00 & 04 & 02 & \\
\hline 3 & District & Men & Women & & & & & \\
\hline & $\begin{array}{c}\text { Jail } \\
\text { Mahoba }\end{array}$ & 331 & 11 & & 44 & 0 & 7 & 02 \\
\hline & & & & $\begin{array}{c}\text { Under } \\
\text { trial }\end{array}$ & Convicts & $\begin{array}{l}\text { Under } \\
\text { trial }\end{array}$ & Convicts & \\
\hline & & & & 33 & 11 & 04 & 03 & \\
\hline
\end{tabular}

This data shows the status of jail inmates in 04 districts in Bundelkhand in the year 2012.

The two districts of Banda and Chitrkoot share a common prison. In the year 2012 out of the total 43 women in jail from the two districts 31 women have been detained under S-498A. Out of these 22 women are under trials and only 09 of them are convicts. There are 08 children living with their mothers in this jail.

In the Hamirpur jail out of the total number of 13 women 06 are detained under S-498A. Out of these 
02 have been convicted and 04 are under trial. There are 02 children living with their mothers in this jail.

In the district jail of Mahoba out of 11 women in jail 07 are under S-498A.Out of these 03 are convicts and 04 are under trials. There are 02 children living with their mothers in this jail.

Analyzing the above data, it is shocking to see that a staggering $72 \%$ of women jail inmates in the district jail of Banda and Chitrkoot, $46 \%$ of women jail inmates in Hamirpur district and $63 \%$ of women jail inmates in Mahoba district respectively are detained under Sec. 498-A The data shows that conviction is low and the law is not a deterrent as awareness, knowledge about the law is négligeable.

On questioning the women inmates if they had any prior knowledge about the anti-dowry law, they all responded in negation. At least $20 \%$ of the women jail inmates under 498A had more than one relative accompanying them in jail.

The data reaffirms the rural urban divide in terms of awareness, empowerment and economic dependence of women.

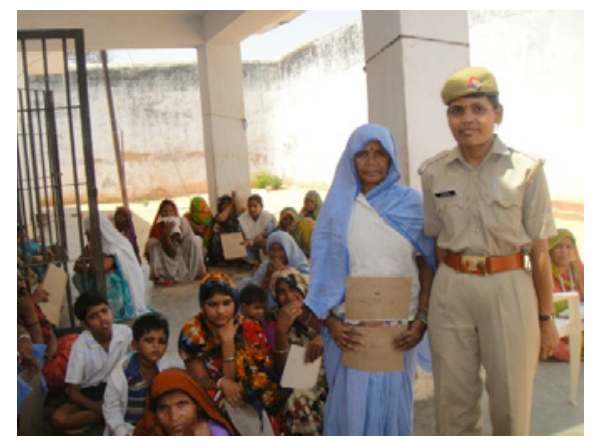

Figure 2. Women and children in jail

Convicts are in blue sarees and the rest are under trials.

\section{Literacy as a measure of reform}

In order to understand, whether illiteracy is the reason why so many women are being killed in rural India, the data of literacy rates of the four districts were collected. Unexpectedly the data brings up an interesting angle to this research.

District wise literacy percentage list of Bundelkhand in Uttar Pradesh in India.

Table 3. Literacy rates. Source-Government of UP data

\begin{tabular}{|c|c|c|c|c|}
\hline $\begin{array}{c}\text { S1. } \\
\text { No. }\end{array}$ & $\begin{array}{c}\text { District's } \\
\text { Name }\end{array}$ & Male & Female & Total \\
\hline 1 & Banda & 79.38 & 54.95 & 68.11 \\
\hline 2 & Chitrakoot & 77.42 & 54.03 & 66.52 \\
\hline 3 & Mahoba & 77.72 & 54.65 & 66.94 \\
\hline 4 & Hamirpur & 81.27 & 57.19 & 70.16 \\
\hline
\end{tabular}

We can see that even though there is more than $77 \%$ literacy rate in men and more than $54 \%$ literacy rate in women yet the cases of bride burning and harassment are increasing. Thus, now, the definition of literacy comes into question. As per government agenda the ability to read and write a single page qualifies one to be literate. The National Literacy Mission defines literacy as acquiring the skills of reading, writing and arithmetic and the ability to apply them to one's day-to-day life [6] The National Literacy Movement Program means not only learning how to read, write and count but also helping people become aware of why they are deprived and helping them move towards change.

As a part of research and as an awareness drive, a one-page government ruling was distributed among the prisoners. This page informed of free legal service provided for those below poverty line. Yet, none of the prisoners could comprehend the full meaning without assistance. Thus, we understand that just literacy rate alone cannot be considered a benchmark for change. In any case school dropout rate is very high for girls as they are expected to help with cooking and rearing their siblings. The percentage of women completing higher education is significantly low.

\section{Children in Jail along with Mothers}

Ironically this law may sometimes work against the victim themselves. This is a photograph of malnourished and sick looking, one-year-old 'Priyanshi' living in jail with her grandmother. Her mother was brought to the hospital with $95 \%$ burns and declared dead. Soon her grandfather, her father, her uncle (father's brother) and his wife, her father's unmarried sister were arrested under Sec.498A as under trials. Ironically Priyanshi herself is taken care of by her grandmother who is her mother's alleged murderer. If her grandmother gets convicted for her crime, Priyanshi will continue to live in jail with her grandmother.

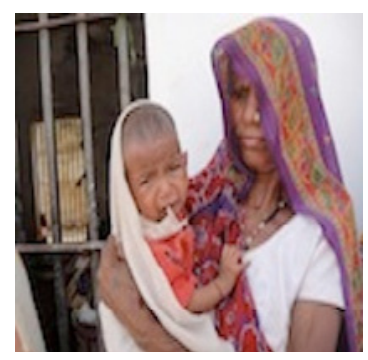

Figure 3. actual photo

A study undertaken by Delhi Commission for Protection of Child Rights(DCPCR) reveals that 56 such children below the age of six are lodged in Delhi's prisons along with their mothers as per 2011 data.

The study, titled " Children of Prisoners - A Rights based Perspective", highlights the plight of about 871 children who are imprisoned in 117 jails in Delhi, Goa, Gujarat, Puducherry , Punjab, Rajasthan, Uttar Pradesh and West Bengal. These children are prone to psychological problems, physical abuse and stunted development due to lack of facilities, the study points out.

To overcome the problem the report suggests that the states step up measures so that the benefits of various welfare schemes like Integrated Child Protection scheme(ICPS) and Integrated Child Development Scheme(ICDS) can reach these children. It also 
recommends that the government should make efforts to trace prisoners' children - aged below 18 - living outside jails. " A detailed plan of action must be chalked out for the rehabilitation and they must be bought under the Juvenile Justice (Care and Protection of children Act 2000), the study underlines. Alternate methods of sentencing like parole, probation, bail and community sentencing must be explored for the mothers of the children below six, to reduce the psychological stress of the child. It is time to give in-depth consideration to the existing legal mechanisms so that rights of children in jail with mothers can be safeguarded". [7]

\section{Measures in Equality}

In most cultures, and in india especially, it is the mother who instills in the girl child a sense of her difference.[8] It is the family and society around us that instills the traditional values as something unchangeable , fixed and unalterable.

Change in society occurs when we challenge stereotypes. Social expectations are justified on the grounds of biology, yet they can be challenged as women can successfully work and succeed in all walks of life.

Media messages can show women in a more enabling and empowering roles and not just as objects of lust and desire.

Textbooks can be re-written in such a way that we present men and women as being not really all that different. Male and female roles and functions can also be shown reversible. Usually school books illustrate women in the conventional role as homemakers and mothers. Men should understand that norms of masculinity limit them, can in fact prove oppressive as men are just as capable of emotions as women are. They also emote love for their children and loved one's, though the norm is that men do not cry or express emotions publicly.

The government can be persuaded to reserve a certain number of posts for women in all departments, including legislative bodies.

Social protection can be designed keeping women in mind. Gender is rarely used as a differentiating lens through which to understand poor people's exposure to risk and vulnerability and to design social protection accordingly. [9]

\section{Conclusion}

The basic principle of criminology is that laws can only be operational when directed at those who are seen as deviants from commonly valued social norms. If they target entire populations who view the efforts of reformers as unwanted meddling in their home affairs, a powerful wave of resentment is created, which barricades, rather than supports, struggles at community level. Laws work well when they embody a strong social unanimity in their support. Even the best of laws become fruitless if they go against universally held theories of facts and impressions.
The stringent law has not acted as a deterrent as assumed. Perhaps the problem of bride burning and harassment need to be looked afresh keeping in mind that feminist intervention ought to focus on change in the attitude of gender discrimination at family and community level rather than just through the law enforcement agencies. With every case of bride burning the whole family and children are affected and yet the number of cases being reported is increasing every year.

Sadly, there are any number of cases coming to light where Section 498A has been used mainly as an instrument of blackmail. It lends itself to easy misuse as a tool for wreaking vengeance on entire families, because, under this section, it is available to the police to arrest anyone a married woman names as a tormentor in her complaint, as "cruelty" in marriage has been made a non-bail able offence. Thereafter, bail in such cases has been denied as a basic right. Such a drastic paradigm shift has lent itself to gross abuse, because arresting and putting a person in jail, even before the trial has begun, amounts to pre-judging and punishing the accused without due process. Although a preliminary investigation is required after the registration of the F.I.R, in practice such complaints are registered, whether the charges are proved valid or not, and arrest warrants issued, without determining whether the concerned family is actually abusive, or they have been falsely implicated. For example, there are a number of cases where the problem is mutual maladjustment of the couple rather than abuse by the entire joint family. However, a host of relatives, including elderly parents, who are not necessarily the cause of maladjustment, have all been arrested and put in jail for varying lengths of time before the trial begins.[10]

It should not, after all, surprise us to discover that the sphere of culture is made not found, that traditions are in flux, and in general that a selective and patriarchal- historical process is always at work. [11] These can be utilized to improve the situation of women by counseling men specially in the rural area to understand the worth of work done by their wives. Traditionally, women's work done in the home, in fields and for livestock is taken for granted and not defined in monetary terms. The argument that surfaces is that since women are biologically enabled to bear children they should also take care of nurturing and food related needs of the family. But little worth is given to this work and women have little access to money or the decision making in the family. If families realize the worth of women's role in both production and reproduction there will be more respect for women and their work and lesser cases of domestic violence or so called dowry killings will occur.

This paper highlights the leanings and distresses of this law prevailing in this region. While the lack of wholesome legislation is one problem, improper implementation of existing legislation is the other problem. The paper also brings forth the impact of the legislative reforms at the grass root level and questions the effectiveness of the laws alone to curtail genderbased violence, when the basic values within the family, 
community and state remain patriarchal and against women. There is large-scale gender discrimination as far as economic empowerment; livelihood choices and value systems are concerned. The need to urge for a more wide-ranging and nuanced framework of rights to counter the current trend of gender based killings and violence is thus acute and pressing.

\section{References}

1. The Dowry Probition Act, 1961.

2. VGeetha .Gender126, NewDelhi,Stree(2006)

3. R.Kumar, The History of Doing-An Illustrated Account of Movements for Women's rights and Feminism in India 1800-1900 New.Delhi: Kali for Women(1993).

4. Madhu, Kishwar, 'Destined to fail- Inherent Flaws in the Anti Dowry Legislation'. Manushi,(148),May-June, 3-12 (2005)
5. Flavia Agnes "Violence against women in South Asia" article in a conference, on "Building capacities on gender responsive government in India", 6 (2012)

6. Wikepedia- the free encyclopedia- Definition of literacy.

7. Sarita Saragi., from study based report complied byher as DCPCR member

8. VGeetha, Gender126, NewDelhi,Stree(2006)

9. Luttrell and Moser (2004).

10. Madhu Kishwar "Strategies for Combating the Culture of Dowry and Domestic Violence in India" Manushi, article for UN Division for the Advancement of Women(2005)

11. Mary E John - Feminism in India and the West, Cultural Dynamics, Vol.10,No. 2 July (1998) 